\title{
Geochemistry of the eocretacic basalt magmatism in the Piraju-Ourinhos region, SE Brazil, and implications to the stratigraphy of the Serra Geral Formation
}

\author{
Valdecir de Assis Janasi ${ }^{1}$, Francisco de Assis Negri², Tarcísio José Montanheiro ${ }^{2}$, Vivian Azor \\ de Freitas ${ }^{1}$, Brenda Chung da Rocha ${ }^{1}$ \& Pedro Morais Reis ${ }^{1}$
}

\begin{abstract}
The Serra Geral Fm. in the Piraju-Ourinhos region (SW of the State of São Paulo) is made up of initial flows of acidic composition which were deposited over the sandstones of the Botucatu Fm., and were covered by basalt flows which crop out north of the Paranapanema river. Geochemical analyses of a suite of extrusive and intrusive basic rocks reveal significant variations that can be used as tools for stratigraphic correlation. All the rocks from flows and a significant proportion of the intrusive rocks show affinity with the Pitanga basalt type. A set of dike rocks, however, shows lower Ti/Y ratios and weakly fractionated primitive mantle-normalized incompatible element patterns, and are interpreted as conduits of younger basalt flows, now eroded, and equivalent to the Paranapanema type. Samples from one sill, on the other hand, are characterized by more fractionated incompatible element patterns and high Sr contents, indicative of the presence of Urubicitype magmas, previously unknown in this region.
\end{abstract}

Keywords: basalt, dacite, Serra Geral Fm., Paraná Magmatic Province, chemical stratigraphy.

Resumo Geoquímica do magmatismo basáltico eocretácico na região de Piraju-Ourinhos, SE do Brasil, e implicações para a estratigrafia da Formação Serra Geral. A Formação Serra Geral na região de Piraju-Ourinhos (SW de São Paulo) é consituída por derrames iniciais de composição ácida, que recobriram os arenitos da Fm. Botucatu e foram cobertos por derrames basálticos, que afloram a norte do rio Paranapanema. Análises geoquímicas de uma suite de rochas básicas extrusivas e intrusivas revelam variações significativas, que podem ser usadas como ferramentas de correlação estratigráfica. Todas as amostras de rochas de derrame e uma proporção significativa das amostras de corpos intrusivos têm afinidade com os basaltos do tipo Pitanga. Um conjunto de rochas de dique, contudo, mostra menores razões Ti/Y e padrões de elementos incompatíveis pouco fracionados, e é interpretado como condutos de derrames basálticos mais jovens, equivalentes ao tipo Paranapanema, já erodidos na região. Amostras de um sill, por outro lado, se caracterizam por padrões de elementos incompatíveis mais fracionados, e elevados teores de $\mathrm{Sr}$, indicando a presença de magmas tipo Urubici, previamente desconhecida na região.

Palavras-chave: basalto, dacito, Fm. Serra Geral, Província Magmática Paraná, estratigrafia química.

INTRODUCTION Determining the stratigraphy of the dominantly basaltic flows which make up the Serra Geral Formation in the Paraná Basin is fundamental for the understanding of the eocretacic geological evolution in south Brazil, and the tectonic significance of the Paraná-Etendeka Magmatic Province (PEMP). The seemingly monothonous sequence of lava flows and the lack of consistent stratigraphic markers turns this into a difficult task. However, similarly to what is observed in other continental basalt provinces (Beane et al., 1986; Reidel, 1998), it has been demonstrated that significant geochemical contrasts can be identified and successfully used as tools for stratigraphic correlation (Peate et al., 1992; Peate, 1997).

The immense area of exposition of the PEMP, which configures it as the second larger continental basalt province in Planet Earth, has stimulated research on a regional scale, which succeeded in defining the general framework of the magmatism, as well as determining its duration and the area distribution of the main geochemical types (Bellieni et al, 1986, 1988; Stewart et al., 1996; Peate, 1997). There is, however, a remarkable lack of studies in a detail scale, which are important for application in engineering geology and mineral prospection, and also for more refined petrological studies.

This work presents the initial results of a geochemical study of basaltic rocks in the Piraju-Ourinhos region (States of São Paulo and Paraná), trying to use their signatures as stratigraphic markers. In this area, the basalts occur as flows, dikes and sills, and generally post-date the initial flows which have acidic (rhyodacite) composition, and are the subject of another contribution (Janasi et al., submitted). 
THE PARANÁ-ETENDEKA MAGMATIC PROVINCE (PEMP)

General aspects The Paraná-Etendeka Magmatic Province ( 138-127 Ma) represents one of the largest volcanic events of Planet Earth, extending for about $1,200,000 \mathrm{~km}^{2}$ in central-south Brazil and neighboring countries (Paraguay, Argentina and Uruguay); the occurrences in Etendeka, Namibia, represent the continuity of the province in the African continent. The volume of lavas is estimated at c. $800,000 \mathrm{~km}^{3}$, with maximum thicknesses reaching locally $1,700 \mathrm{~m}$ at the central axis of the Paraná Basin. Tholeiitic basalts are largely predominant ( $>70 \%$ in volume), and were initially divided in two subtypes: those with high $\mathrm{TiO}_{2}$, predominant in the northern portion of the Paraná Basin, and those with low $(<2 \%) \mathrm{TiO}_{2}$, in the south (e.g., Peate, 1997). More detailed geochemical and isotopic studies, including continuous stratigraphic sections studied in the field or obtained from sampling of deep boreholes allowed a more detailed basalt typology to be defined, and seven main types were distinguished, four with high $\mathrm{TiO}_{2}$ and three with low $\mathrm{TiO}_{2}$ (Peate, 1997). Intermediate and acid volcanic rocks area more common in the SE portion of the Paraná Basin, where a variety described as Palmas type, having some chemical affinities with the low- $\mathrm{TiO}_{2}$ basalts, is predominant. Less volumetrically important occurrences in the center-north portion of the Paraná Basin (States of Paraná and São Paulo) are recognized as a second type (Chapecó), which shows geochemical and isotopic affinities with the high-Ti basalts.

Precise estimates of the age of the volcanism were only possible with the obtaintion of Ar-Ar ages during the 1990 decade, and suggest an age migration from NNW (138-135 Ma) to SE (131-127 Ma); the main volume of magmas was generated in a small time interval ( 5 Myr., from 135 to $131 \mathrm{Ma}$; Stewart et al., 1996), during which some northward migration of the magmatism seems to have occurred locally (Ernesto et al., 1999).

Typology of the basalt magmatism Rocks with basic to intermediate character (tholeiitic basalts and basaltic andesites) correspond to ca. $97.5 \%$ of the total magma volume, and are assigned to the Serra Geral Fm. which covers pre-volcanic sediments of the Paraná Basin (from younger to older, Botucatu Fm., Passa Dois Group, Tubarão Group). Province-wide compositional variations have been recognized since the pioneering works by Ruegg \& Amaral (1976), and use as the main parameter the Ti contents. In general terms, in the northern and western portions of the Paraná Basin the basalts are richer in $\mathrm{Ti}(\mathrm{TiO} 2>2 \%$; $\mathrm{Ti} / \mathrm{Y}>350)$, while the basalts in the SE portion of the basin show lower Ti contents $(\mathrm{TiO} 2<2 \%$; $\mathrm{Ti} / \mathrm{Y}<330)$, and are poorer in incompatible elements such as $\mathrm{P}, \mathrm{Sr}, \mathrm{Zr}, \mathrm{La}, \mathrm{Ce}$ and $\mathrm{Ba}$. Studies of geochemical correlation in a regional scale based in geological profiles in exposed sections and sampling of deep boreholes led Peate et al. (1992) to propose a more detailed subdivision in the PEMP, which were classified into seven main types, four with high
$\mathrm{Ti} / \mathrm{Y}$ and three with low Ti/Y. The geochemical criteria proposed by Peate et al. (1992) and Peate (1997) are based mostly in ratios between incompatible elements ( $\mathrm{Ti}, \mathrm{Zr}, \mathrm{Y}$ ), the $\mathrm{Sr}$ contents, and the relative abundances of Fe, Mg and Ti. These criteria have been adopted by many authors, who offered new contributions to the refinement of the stratigraphy and distribution of these flows in the Brazilian portion of the PEMP (e.g., Nardy et al., 2002, 2005; Rocha Jr. et al., 2005).

LOCAL GEOLOGY Figure 1 is a synthetic geologic map of the Piraju-Ourinhos region, States of São Paulo and Paraná, which resulted from a geologic mapping at the semi-detail scale $(1: 100,000)$ and integration of pre-existing maps (CPRM, 1980; Raposo, 1987; IPT, 1994).

In this region occur the northernmost exposures of acidic volcanic rocks in the Paraná Basin, outcropping over a $\sim 65 \times 20 \mathrm{~km}$ area elongated N40W which extends from the Paranapanema River, locally between the topogaphic elevations 550 and $450 \mathrm{~m}$, and the "Serra da Fartura", with heights over $800 \mathrm{~m}$. The acidic rocks correspond to the initial flows, resting directly over the Botucatu Fm. sandstones, as already suggested in previous field studies (Raposo, 1987; Iyomasa et al., 1994).

Basalt flows covered the acidic volcanic rocks, and outcrop typically north of the Paranapamema River; they were locally covered, in erosive discordance, by clastic sediments of the Bauru Group (Fig. 1). The basalt areas have scarce outcrops; the few best exposures are found in quarries, most of which are small. These rocks are usually massive and aphyric, but locally may present plagioclase microphenocrysts. The upper portion of the flows is made up of an amigdaloidal glassy level which may locally be over $3 \mathrm{~m}$ thick.

A small window of acidic volcanic rocks exposed by erosion was mapped among the basalts between Ipauçu and Chavantes (Fig. 1), but there are no evidences that these rocks extend in subsurface much to the north.

Intrusive subvolcanic bodies are abundant throughout the area, especially intruding the pre-volcanic sedimentary rocks.

Dikes with acidic composition are subordinate, but were observed immediately below the lower contact of the flows, in a situation indicative that they correspond to feeders (outcrop OU-70). The thickest acidic dikes (over $50 \mathrm{~m}$ ) were observed in the "Serra da Fartura" (outcrop OU-54).

Diabase dikes are usually in the N45W direction and show variable thickness (up to $100 \mathrm{~m}$ ); locally they were observed crosscutting dacite and also basalt flows (cf. Fig. 1; outcrop OU-251); they are nevertheless much more abundant intruding the pre-volcanic sediments, forming swarms (Fig. 1), particularly in the neighborhood of the thickest sills.

Diabase sills are found along discontinuities within or between pre-volcanic sedimentary units, and may form expressive bodies, such as the Fartura 


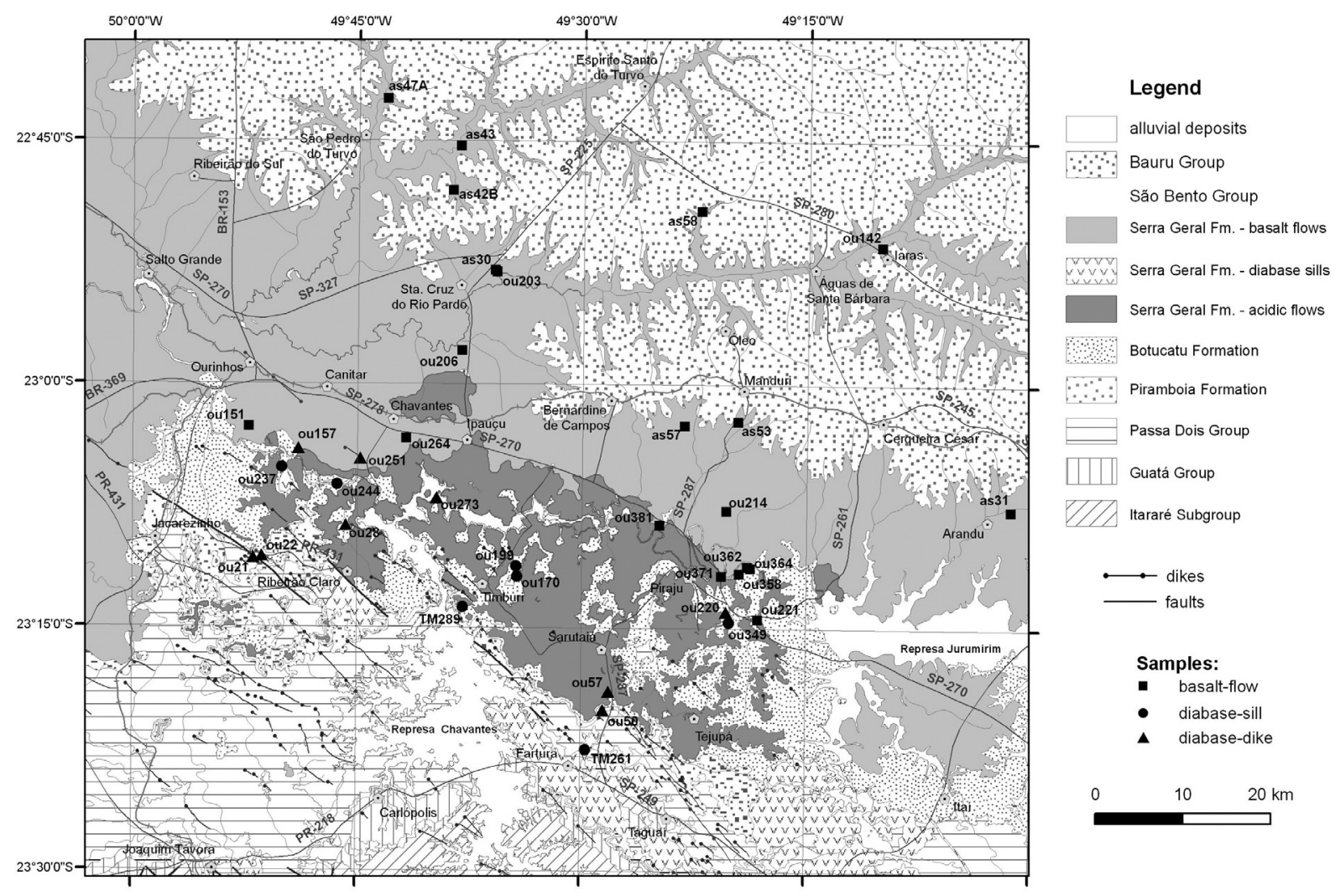

Figure 1 - Simplified geological map of the volcanic rocks and associated hipoabissal intrusives in the Piraju-Ourinhos region (from Negri et al, 2006).

Sill ( $\sim 20$ x $5 \mathrm{~km}$; Fig. 1). A remarkable feature is the presence of such bodies intruding the upper portion of the Botucatu Fm., immediately below the contact with the first dacite flows; this feature was observed in several localities, and is particularly evident in profiles along the "Serra da Fartura" and in sandstone "windows" exposed among the dacites (Fig. 1). Apparently, there are also some diabase sills intruding the basalt flows; in particular, occurrences of phaneritic basic rocks are common in the lower contact of the basalts and may, have crystallized as intrusive bodies (e.g., points OU-157 and OU-358).

Discontinuous levels of inter-trapp sandstone, sometimes up to $20 \mathrm{~m}$ thick, constitute an important stratigraphic mark between different acidic flows and sometimes also mark the lower contact of the first basalt flow (Fig. 1).

\section{PETROGRAPHY}

Basic rocks Aphanitic to very fine-grained basalt occurs dominantly in flows, although they can also be present in some thin dikes. The rocks are nearly aphyric, with occasional phenocrysts of the main minerals, but some samples with up to $10 \%$ vol. phenocrysts were observed (Fig. 2a). Magmatic flow orientation, marked by the alignment of tabular plagioclase crystals, is evident in sample OU-142 (Fig. 2f). The most common texture is intergranular, dominated by tabular plagioclase crystals ( An60-40), clinopyroxene (augite and pigeonite) and granular opaque minerals; apatite is the only abundant accessory, and is concentrated in the mesostasis.
Hydrated glass, with brown to purple color, is absent in most of the samples, but may be abundant in some; it reaches over $25 \%$ in volume in sample OU-221 while it is interstitial and less than 5\% vol. in OU-203a and OU-142. Secondary minerals are green phylosilicates ("clorofeaite"), which partly replace the glass and fills part of the vesicles.

The rocks from sills are distinguished by their fine-grained phaneritic texture ( $\sim 0.3 \mathrm{~mm}$; Fig. $2 \mathrm{~b})$ and absence of glass or products of devitrification; they may exhibit phenocrysts of andesine (up to $3 \mathrm{~mm}$ ), clinopyroxene (up to $1 \mathrm{~mm}$ ) and opaque minerals $(<1$ $\mathrm{mm}$ ). Samples with better developed crystals may show granophyric quartz + alkali feldspar intergrowth in the mesostasis. In some cases where the field relationship does not allow the form of occurrence of the rock to be determined (especially at the lower contact of basalt pile, where phaneritic rocks may have intruded as sills), petrography does not offer unequivocal elements for this distinction.

The rocks from dikes are characterized by finegrained equigranular texture (up to $1 \mathrm{~mm}$ ), and their mineralogy is identical to that of the flows, with calcic plagioclase, clinopiroxene, opaque minerals and apatite. Some of them are distinguished, however, by the presence of patches of glassy material which may constitute up to $30 \%$ vol. of the rock. Usually with a brown color, and bearing skeletal crystals of opaque minerals distributed all through it, the glass (Fig. 2d) has inclusions of minerals with shapes indicative of quenching, such as very elongated and hollow plagio- 
clase crystals. A distinctive pyroxene, with high refractory index and low birrefringence, identified as orthopyroxene, occurs in sample OU-28, where it is bordered by clinopyroxene and partly replaced by green-colored alteration minerals (Fig. 2e).

Acidic rocks The main textural variations observed in the acidic volcanic rocks are in the crystallinity and grain-size of the groundmass, and are directly related to their position in the flows. Rocks with glassy matrix, typical of the flow contacts, exhibit plagioclase phenocrysts with up to $5 \mathrm{~mm}$; microphenocrysts may frequently present geometries indicative of quenching such as hollow crystals and swallow tail terminations. Clinopyroxene, titanomagnetite and apatite also occur as phenocrysts, but are less abundant. The brownishred ("chocolate") color of glassy rocks occurring in the lower contact with sandstones appears to be related to the oxidation of the matrix, which is accompanied, in some rocks, by alteration of the pyroxene phenocrysts.

In rocks with the "salt and pepper" macroscopic texture, there is an interlacing of mm-sized clear, crystalline areas (dominated by intergrown quartz and feldspars plus some pyroxene) and turbid portions, also feldspar-rich, but interpreted as the product of low-temperature hydration of originally glassy material, within which the plagioclase shows quenching features.

In the holocrystalline rocks, characteristic of the inner portion of thick flows or dikes, phenocrysts and amygdules are less abundant, and quartz is always
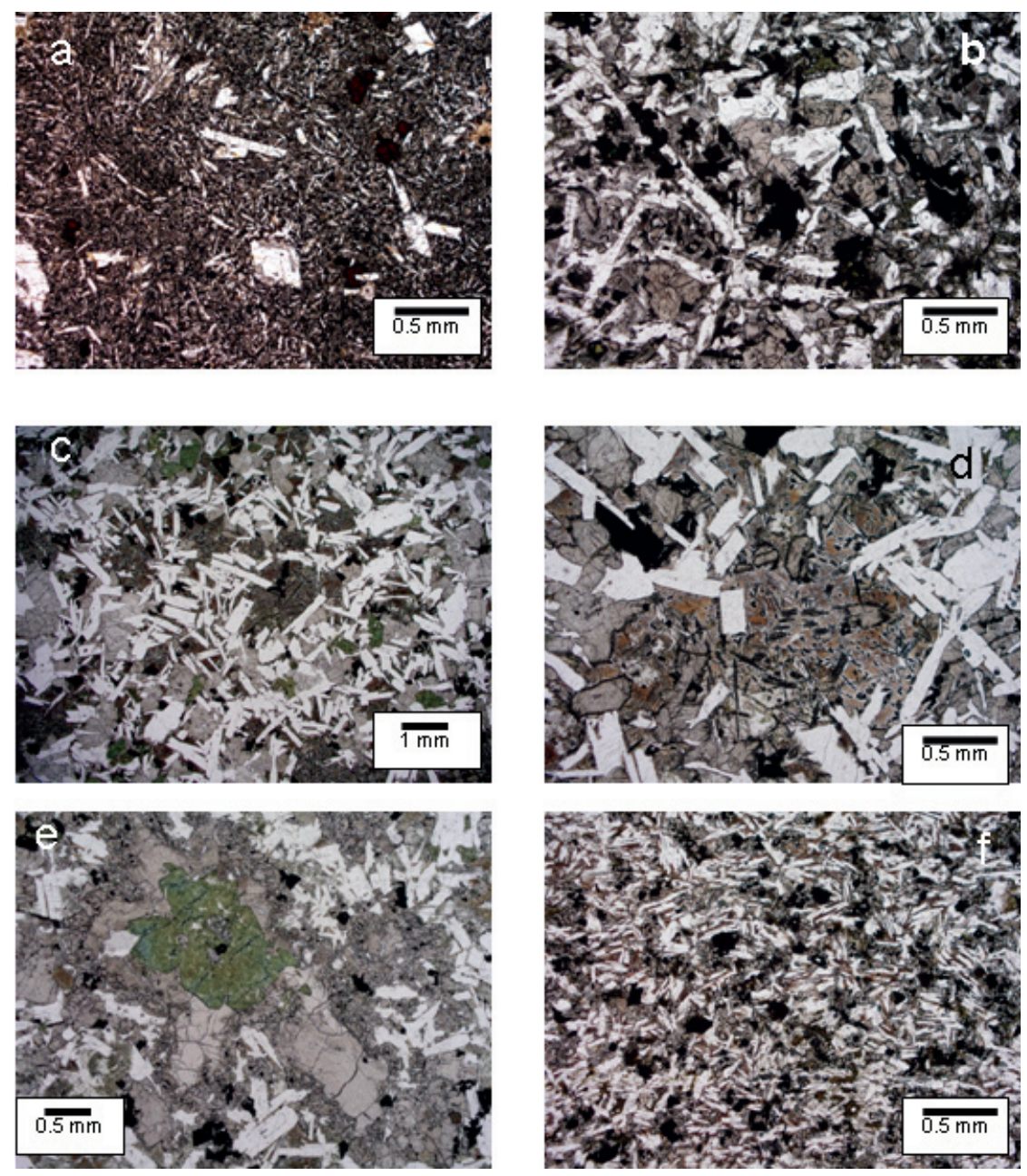

Figure 2 - Textural aspects of the basic rocks from the Piraju-Ourinhos region. (a) basalt with glommeroporphyritic texture (agglomerates of plagioclase and pyroxene phenocrysts), sample OU-204c; (b) general aspect of the intergranular texture of a diabase sample from a sill (OU157); (c) general aspect of the intersertal texture of a diabase sample from a dike (OU-27); dark interconnected patches that are shown in more detail in (d) (sample OU-22) are constituted of devitrified glass that contains skeletal crystals of opaque mineral and plagioclase with swallow tail terminations; (e) orthopyroxene phenocryst partly transformed into green phylossilicate and mantle by clinopyroxene in a diabase dike (sample OU-28); (f) magmatic flow orientation in an aphanitic basalt (sample OU-142). All photomicrographs in plane-polarized light. 
evident at the microscope, usually intergrown with the feldspars.

The plagioclase phenocrysts show normal zoning, in the range An50-40 in samples with glassy matrix; more sodic borders, chemically similar to matrix and microphenocrysts plagioclase (An40-28), are present in rocks with crystalline matrix. Alkali feldspar may rim the plagioclase microphenocrysts and is also an important constituent of the matrix, where it is usually more Or-rich. Two pyroxenes (augite and pigeonite) are present in most of the samples, as scattered phenocrysts and constituents of the groundmass. The amigdales, usually with diameters from 1 to $20 \mathrm{~mm}$, may locally reach decimeter sizes, and are filled with zeolites, calcedony and carbonate minerals. Additional details of the petrography of these acidic rocks are given in Janasi et al. (2005).

\section{GEOCHEMISTRY}

Analytical procedures and quality control Representative rock samples (typically with less than $200 \mathrm{~g}$, in view of the fine grain size) were crushed in a hydraulic crusher; the fragments thus obtained were then powdered in an agate mill to clay size. Chemical analyses of acidic volcanic rocks which are presented in another publication (Janasi et al., submitted) are used in some diagrams for comparison; these samples were prepared using the same method, but in this case the procedure included the manual extraction, after crushing, of post-magmatic (vesicle- and fracture-filling) materials such as zeolites and silica-group minerals.

The analyses of major oxides were obtained from fused glass disks and a set of trace-elements were analysed from pressed powder pellets (cf. results in Table 1) in a Philips PW2100 X-ray Fluorescence Spectrometer at the Instituto de Geociências, Universidade de São Paulo, following the protocol described in Mori et al. (1999). Their quality was controlled by analysing the certified international reference material basalt JB1a and duplicates, and the results were considered satisfactory for both major elements (accuracy better than 2\% relative for oxides with contents over $10 \mathrm{wt} \%$, and better than $5 \%$ for the remaining oxides) and trace-elements (accuracy better than 10\% relative when the contents are 10 times greater than detection limit).

A subset of representative samples was chosen for the analyses of less abundant trace-elements (REE, Th, U, Nb, Ta, Hf etc) by ICPMS (cf. Table 2). A $0.1 \mathrm{~g}$ aliquot of the powdered sample, extracted after homogenization, was dissolved by acid attack using a mixture of $\mathrm{HF}$ and $\mathrm{HNO}_{3}$ in a CETEC $\circledast$ microwave oven for 60 minutes. The solution thus obtained was dried and redissolved in $\mathrm{HNO}_{3}$ and analysed in an ELAN6100 ICPMS at the Instituto de Geociências, Universidade de São Paulo, using a set of international reference materials for calibration. Further details of the procedure and quality control are presented by Navarro (2004).
Nomenclature and comparison with previous analyses The results of XRF chemical analyses obtained in the studied basic rocks are presented in Table 1 and in variation diagrams in figures 3 to 6 .

The results were initially compared with analyses previously available for the region (Raposo, 1987), in order to check for possible analytical differences, and whether or not the whole compositional range was encompassed by the new analyses. The comparison suggests that, for some oxides (e.g., $\mathrm{P}_{2} \mathrm{O}_{5}$ ), the greater dispersion in the older data may be a reflection of lesser precision. It is remarkable, however, that there are
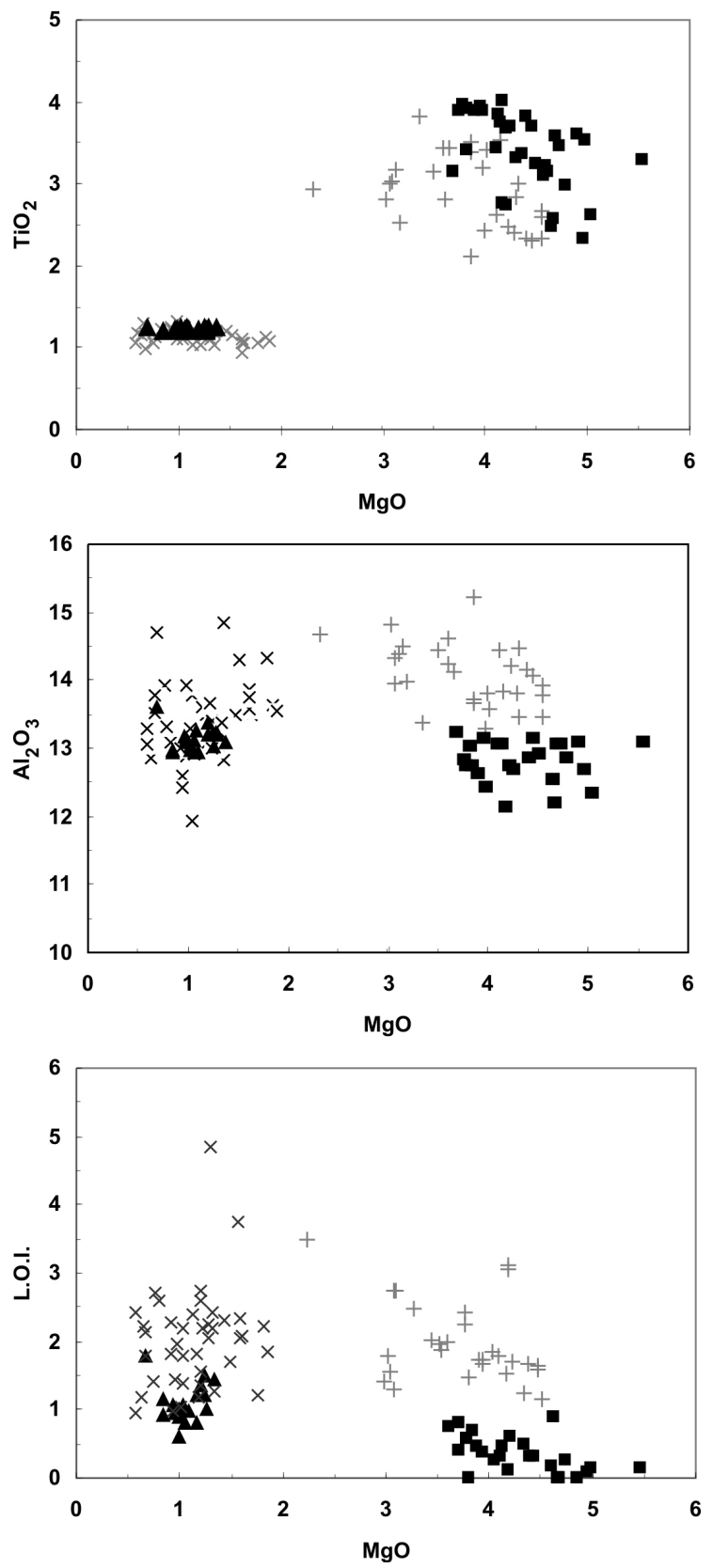

Figure 3 - Binary variation diagrams comparing the results of analyses of selected oxides reported in this work (closed squares, basic rocks; closed triangles, acidic rocks) with data previously reported for the same region (Raposo, 1987; crosses, basic rocks; " $x$ ”, acidic rocks). 


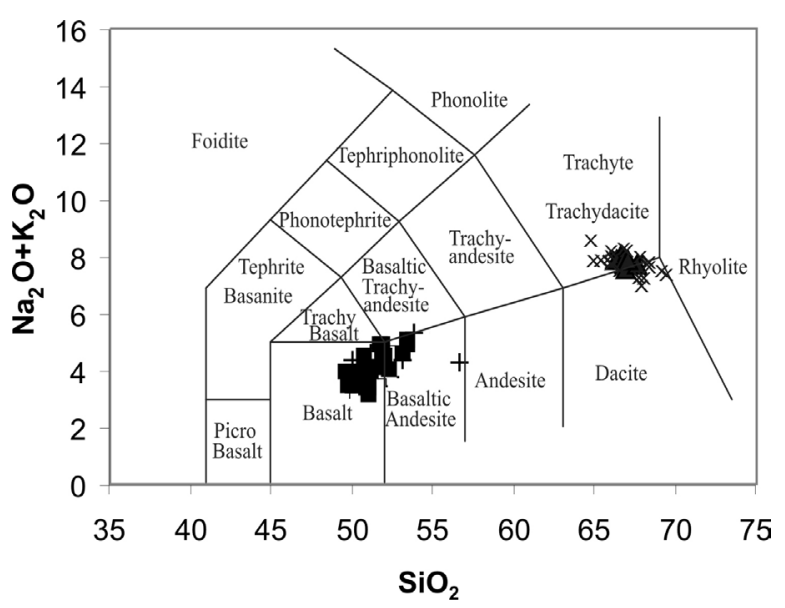

Figure 4 - TAS diagram (Le Bas et al., 1986) used for the nomenclature of basic and acidic volcanic rocks of Piraju-Ourinhos region. Symbols as in Figure 3.
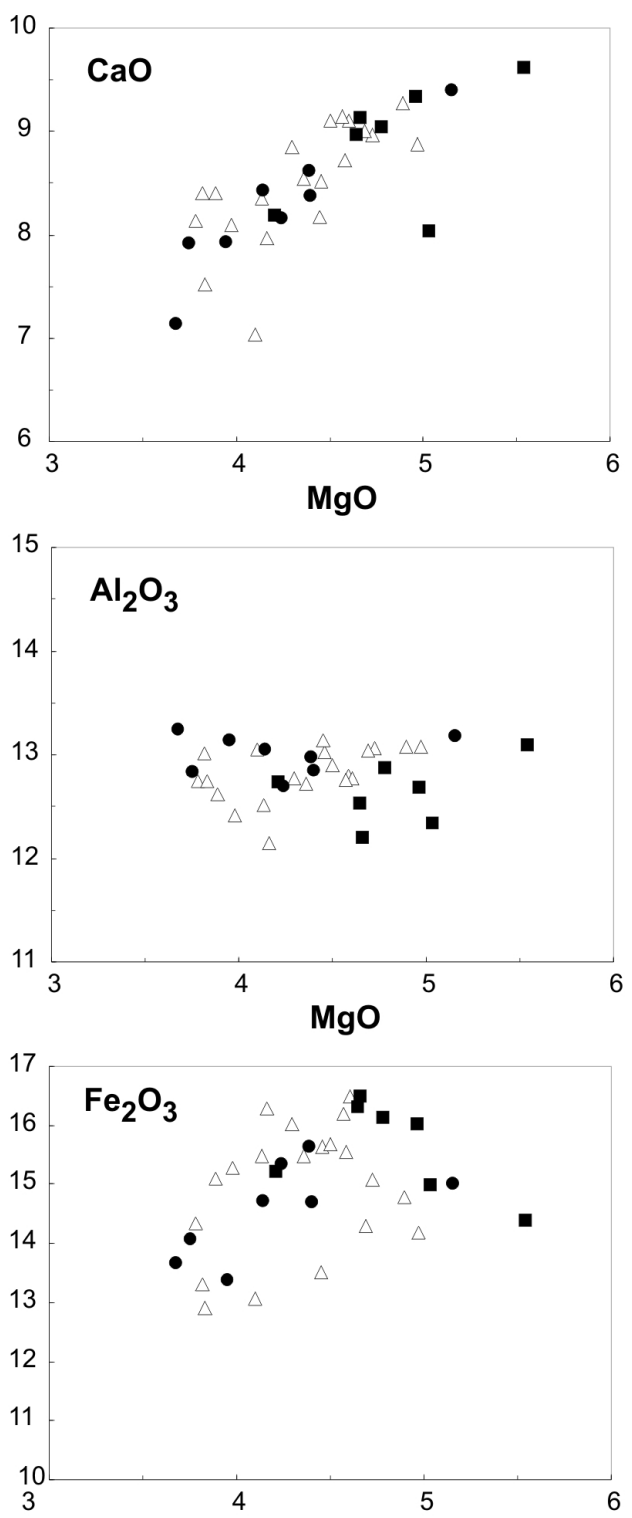

some systematic inter-laboratory differences, of which the more important are the contents of $\mathrm{MgO}$ and $\mathrm{Al}_{2} \mathrm{O}_{3}$. The $\mathrm{MgO}$ contents here reported show the bimodal character of the magmatism: the contents in the basaltic rocks are typically 4 to $5 \mathrm{wt} \%$, while the acidic rocks have between 0.8 and $1.5 \mathrm{wt} \% \mathrm{MgO}$ (Fig. 3). The previous data show a less clearly defined gap, reflecting especially the greater dispersion among the acidic rocks, and an evident tendency to systematically lower $\mathrm{MgO}$ contents as compared to those here reported (3-4.5\%). Another remarkable analytical contrast is in the $\mathrm{Al}_{2} \mathrm{O}_{3}$ content, significantly higher in the previous dataset (13$15 \mathrm{wt} \%$ versus $11.5-13 \mathrm{wt} \%$ in this work).

Figure 4 shows the situation of the studied rocks in the diagram for volcanic rock classification (TAS, Le Bas et al., 1986). The basic rocks are located in the basalt field, with a few samples corresponding to basaltic andesites. The acidic rocks lay typically in the
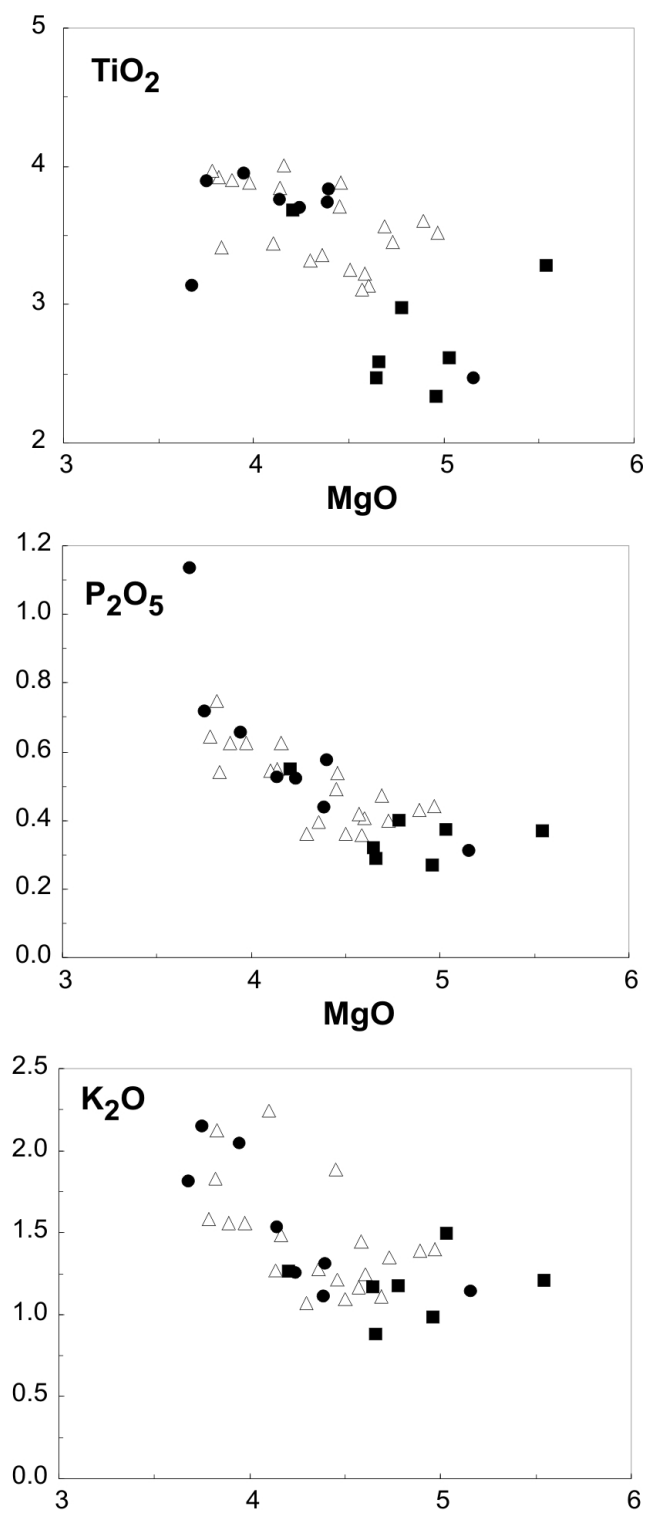

Figure 5 - Major and minor oxide variation diagrams using $\mathrm{MgO}$ as a differentiation index for PEMP basalts from the Piraju-Ourinhos region. Symbols: open triangles: flows; closed circles: sills; closed squares: dikes. 
Table 1 - Results of chemical analyses (by XRF) of basaltic rocks from the Piraju-Ourinhos region

\begin{tabular}{|c|c|c|c|c|c|c|c|c|c|c|c|c|c|c|c|c|c|c|}
\hline Sample & $\begin{array}{l}\text { OU- } \\
142\end{array}$ & $\begin{array}{l}\text { OU- } \\
151\end{array}$ & $\begin{array}{l}\text { OU- } \\
157\end{array}$ & $\begin{array}{l}\text { OU- } \\
203\end{array}$ & $\begin{array}{l}\text { OU- } \\
206\end{array}$ & $\begin{array}{l}\text { OU- } \\
214\end{array}$ & $\begin{array}{l}\text { OU- } \\
221\end{array}$ & $\begin{array}{l}\text { OU- } \\
264\end{array}$ & $\begin{array}{l}\text { OU- } \\
358\end{array}$ & $\begin{array}{l}\text { OU- } \\
362\end{array}$ & $\begin{array}{l}\text { OU- } \\
364\end{array}$ & $\begin{array}{l}\text { OU- } \\
371\end{array}$ & $\begin{array}{l}\text { OU- } \\
381\end{array}$ & $\begin{array}{c}\text { AS- } \\
30\end{array}$ & $\begin{array}{l}\text { AS- } \\
031\end{array}$ & $\begin{array}{l}\text { AS- } \\
47 \mathrm{~A}\end{array}$ & $\begin{array}{l}\text { AS- } \\
47 \mathrm{~B}\end{array}$ & $\begin{array}{l}\text { AS- } \\
053\end{array}$ \\
\hline Occurrence & flow & flow & flow & flow & flow & flow & flow & flow & flow & flow & flow & flow & flow & flow & flow & flow & flow & flow \\
\hline $\mathrm{SiO} 2$ & 49.62 & 51.24 & 51.45 & 49.41 & 49.35 & 49.28 & 50.07 & 50.43 & 52.81 & 50.91 & 50.05 & 50.76 & 53.02 & 50.20 & 50.51 & 49.00 & 49.27 & 50.28 \\
\hline $\mathrm{TiO} 2$ & 3.421 & 3.663 & 3.877 & 3.205 & 3.82 & 3.573 & 3.853 & 3.526 & 3.396 & 3.879 & 3.965 & 3.838 & 3.383 & 3.20 & 3.50 & 3.09 & 3.06 & 3.31 \\
\hline $\mathrm{A} 12 \mathrm{O} 3$ & 12.93 & 12.96 & 12.88 & 12.72 & 12.81 & 12.97 & 12.46 & 12.88 & 12.89 & 12.46 & 12.02 & 12.27 & 12.65 & 12.68 & 13.00 & 12.57 & 12.56 & 12.52 \\
\hline $\mathrm{Fe} 2 \mathrm{O} 3 \mathrm{t}$ & 14.93 & 13.32 & 13.17 & 15.47 & 15.38 & 14.66 & 14.91 & 14.11 & 12.89 & 14.02 & 16.12 & 15.11 & 12.80 & 15.40 & 14.09 & 16.22 & 15.95 & 15.22 \\
\hline $\mathrm{MnO}$ & 0.208 & 0.174 & 0.195 & 0.217 & 0.198 & 0.231 & 0.211 & 0.222 & 0.190 & 0.193 & 0.228 & 0.214 & 0.188 & 0.214 & 0.212 & 0.207 & 0.235 & 0.232 \\
\hline $\mathrm{MgO}$ & 4.68 & 4.39 & 3.78 & 4.44 & 4.38 & 4.85 & 3.84 & 4.63 & 4.05 & 3.70 & 4.12 & 3.93 & 3.80 & 4.54 & 4.94 & 4.53 & 4.5 & 4.29 \\
\hline $\mathrm{CaO}$ & 8.87 & 8.06 & 8.32 & 8.98 & 8.38 & 9.19 & 8.30 & 8.89 & 6.95 & 7.95 & 7.89 & 8.00 & 7.46 & 8.64 & 8.82 & 8.96 & 9.00 & 8.41 \\
\hline $\mathrm{Na} 2 \mathrm{O}$ & 2.59 & 2.79 & 2.74 & 2.71 & 2.28 & 2.60 & 2.94 & 2.49 & 2.82 & 2.52 & 2.52 & 2.57 & 2.82 & 2.41 & 2.49 & 2.22 & 2.33 & 2.48 \\
\hline $\mathrm{K} 2 \mathrm{O}$ & 34 & 1.86 & 1.81 & 1.08 & 1.19 & 1.38 & 1.54 & 1.10 & 2.22 & 1.55 & 1.47 & 1.54 & 2.11 & 1.43 & 1.39 & 1.23 & 1.15 & 1.26 \\
\hline $\mathrm{P} 2 \mathrm{O} 5$ & 0.393 & 0.483 & 0.738 & 0.354 & 0.526 & 0.426 & 0.617 & 0.465 & 0.538 & 0.629 & 0.619 & 0.619 & 0.536 & 0.352 & 0.44 & 0.401 & 0.411 & 0.389 \\
\hline LOI & - & 0.33 & 0.58 & 0.32 & 0.99 & - & 0.68 & 0.89 & 0.27 & 0.82 & 0.45 & 0.38 & - & 0.49 & 0.32 & 1.22 & 1.42 & 0.7 \\
\hline Total & 98.98 & 98.98 & 99.54 & 98.91 & 99.30 & 99.16 & 99.42 & 99.63 & 99.02 & 98.63 & 99.45 & 99.23 & 99.23 & 99.55 & 99.713 & 99.647 & 99.883 & 99.088 \\
\hline
\end{tabular}

trace elements (in ppm)

\begin{tabular}{|c|c|c|c|c|c|c|c|c|c|c|c|c|c|c|c|c|c|c|}
\hline $\mathrm{Ba}$ & 482 & 472 & 562 & 436 & 499 & 546 & 546 & 448 & 539 & 1105 & 525 & 534 & 554 & 397 & 423 & 460 & 686 & 513 \\
\hline $\mathrm{Ce}$ & 87 & 79 & 117 & 63 & 93 & 90 & 90 & 100 & 119 & 128 & 130 & 128 & 63 & 105 & 86 & 100 & 94 & 77 \\
\hline $\mathrm{Co}$ & 38 & 35 & 38 & 34 & 35 & 35 & 45 & 46 & 23 & 52 & 35 & 43 & 22 & 36 & 32 & 36 & 38 & 36 \\
\hline $\mathrm{Cr}$ & 26 & 46 & 8 & 33 & 21 & 55 & - & 53 & 21 & - & 14 & - & 36 & 31 & 55 & 39 & 41 & \\
\hline $\mathrm{Cu}$ & 122 & 51 & 167 & 120 & 176 & 228 & 165 & 141 & 52 & 244 & 164 & 166 & 37 & 127 & 130 & 221 & 219 & 169 \\
\hline $\mathrm{F}$ & - & 859 & 606 & - & 1362 & - & - & 669 & 729 & 792 & 893 & 772 & 685 & 1004 & 552 & 1118 & 1292 & 725 \\
\hline $\mathrm{Ga}$ & 25 & 26 & 27 & 25 & 25 & 24 & 26 & 24 & 25 & 25 & 24 & 24 & 24 & 24 & 24 & 21 & 22 & 24 \\
\hline $\mathrm{La}$ & 33 & 38 & 42 & 32 & 43 & 47 & 47 & 40 & 40 & 69 & 39 & 46 & 36 & - & 36.2 & - & - & 36.3 \\
\hline $\mathrm{Nb}$ & 25 & 27 & 29 & 23 & 24 & 22 & 30 & 20 & 27 & 28 & 29 & 28 & 28 & 20 & 20 & 19 & 18 & 21 \\
\hline $\mathrm{Nd}$ & 41 & 43 & 59 & 36 & 55 & 32 & 35 & 57 & 52 & 62 & 74 & 58 & 59 & 50 & 42 & 45 & 48 & 55 \\
\hline $\mathrm{Ni}$ & 41 & 32 & 34 & 33 & 29 & 57 & 24 & 66 & 29 & 29 & 24 & 29 & 30 & 37 & 56 & 41 & 42 & 28 \\
\hline $\mathrm{Pb}$ & 6 & 8 & 10 & 5 & 5 & 6 & 7 & 4 & 8 & 5 & 7 & 8 & 10 & 7 & 4 & 9 & 6 & 5 \\
\hline $\mathrm{Rb}$ & 20 & 41 & 40 & 27 & 21 & 36 & 36 & 24 & 46 & 35 & 35 & 35 & 47 & 27 & 27 & 34 & 33 & 25 \\
\hline $\mathrm{S}$ & - & - & - & - & - & - & - & - & - & - & 210 & 348 & - & - & - & - & - & - \\
\hline $\mathrm{Sc}$ & 32 & 32 & 30 & 33 & 32 & 34 & 32 & 31 & 26 & 35 & 33 & 34 & 29 & 31 & 30 & 33 & 37 & 34 \\
\hline $\mathrm{Sr}$ & 535 & 483 & 515 & 444 & 496 & 502 & 502 & 484 & 474 & 528 & 489 & 505 & 460 & 445 & 465 & 388 & 379 & 455 \\
\hline $\mathrm{Th}$ & 11 & 11 & 10 & 10 & 9 & 11 & 11 & 7 & 8 & 8 & 10 & 8 & 31 & 8 & 11 & 10 & 10 & 9 \\
\hline $\mathrm{U}$ & 8 & 8 & 8 & 9 & - & 9 & 9 & 3 & 3 & 4 & 5 & 4 & - & - & - & - & - & - \\
\hline $\mathrm{V}$ & 467 & 382 & 381 & 455 & 420 & 458 & 390 & 416 & 360 & 394 & 419 & 406 & 343 & 474 & 429 & 476 & 474 & 461 \\
\hline $\mathrm{Y}$ & 40 & 38 & 45 & 130 & 39 & 42 & 42 & 40 & 41 & 51 & 40 & 41 & 41 & 34 & 34 & 36 & 37 & 36 \\
\hline $\mathrm{Zn}$ & 121 & 127 & 140 & 130 & 130 & 124 & 146 & 121 & 126 & 154 & 144 & 149 & 120 & 119 & 113 & 126 & 123 & 128 \\
\hline $\mathrm{Zr}$ & 252 & 296 & 318 & 230 & 268 & 310 & 310 & 243 & 323 & 308 & 307 & 307 & 317 & 218 & 230 & 202 & 198 & 242 \\
\hline
\end{tabular}


Table 1(cont.) Results of chemical analyses (by XRF) of basaltic rocks from the Piraju-Ourinhos region

\begin{tabular}{l|c|c|c|c|c|c|c|c|c|c|c|c|c|c|c|c|c}
\hline Sample & AS-057 & AS-058 & $\begin{array}{c}\text { OU- } \\
170\end{array}$ & $\begin{array}{c}\text { OU- } \\
199\end{array}$ & $\begin{array}{c}\text { OU- } \\
220\end{array}$ & $\begin{array}{c}\text { OU- } \\
237\end{array}$ & $\begin{array}{c}\text { OU- } \\
244\end{array}$ & $\begin{array}{c}\text { OU- } \\
349\end{array}$ & $\begin{array}{c}\text { TM- } \\
261\end{array}$ & $\begin{array}{c}\text { TM- } \\
289\end{array}$ & $\begin{array}{c}\text { OU- } \\
021\end{array}$ & $\begin{array}{c}\text { OU- } \\
022\end{array}$ & $\begin{array}{c}\text { OU- } \\
028\end{array}$ & $\begin{array}{c}\text { OU- } \\
050\end{array}$ & $\begin{array}{c}\text { OU- } \\
057\end{array}$ & $\begin{array}{c}\text { OU- } \\
251\end{array}$ & $\begin{array}{c}\text { OU- } \\
273\end{array}$ \\
\hline $\begin{array}{l}\text { Occur- } \\
\text { rence }\end{array}$ & flow & flow & sill & sill & sill & sill & sill & sill & sill & sill & dike & dike & dike & dike & dike & dike & dike \\
\hline SiO2 & 50,38 & 49,95 & 51,00 & 50,99 & 50,62 & 52,15 & 50,33 & 50,62 & 50,30 & 49,44 & 50,89 & 50,77 & 51,92 & 50,93 & 49,49 & 49,38 & 50,67 \\
\hline TiO2 & 3,79 & 3,28 & 3,836 & 3,885 & 3,732 & 3,081 & 3,782 & 3,668 & 2,44 & 3,68 & 3,653 & 2,323 & 2,591 & 2,577 & 2,944 & 3,242 & 2,447 \\
\hline $\mathrm{A} 2 \mathrm{O} 3$ & 12,35 & 12,60 & 12,66 & 12,92 & 12,96 & 13,00 & 12,68 & 12,57 & 13,04 & 12,74 & 12,65 & 12,62 & 12,23 & 12,19 & 12,73 & 12,92 & 12,43 \\
\hline $\mathrm{Fe} 2 \mathrm{O} 3 \mathrm{t}$ & 15,26 & 15,80 & 13,88 & 13,15 & 14,61 & 13,42 & 14,51 & 15,20 & 14,84 & 15,35 & 15,11 & 15,94 & 14,87 & 16,47 & 15,95 & 14,20 & 16,19 \\
\hline $\mathrm{MnO}$ & 0,209 & 0,217 & 0,165 & 0,170 & 0,191 & 0,222 & 0,200 & 0,204 & 0,212 & 0,222 & 0,207 & 0,227 & 0,219 & 0,234 & 0,213 & 0,199 & 0,229 \\
\hline $\mathrm{MgO}$ & 4,08 & 4,24 & 3,70 & 3,88 & 4,11 & 3,61 & 4,34 & 4,20 & 5,10 & 4,31 & 4,18 & 4,94 & 4,99 & 4,66 & 4,73 & 5,47 & 4,61 \\
\hline $\mathrm{CaO}$ & 8,24 & 8,73 & 7,81 & 7,80 & 8,37 & 7,01 & 8,27 & 8,09 & 9,30 & 8,47 & 8,13 & 9,29 & 7,97 & 9,12 & 8,95 & 9,49 & 8,89 \\
\hline $\mathrm{Na} 2 \mathrm{O}$ & 2,55 & 2,46 & 2,77 & 2,84 & 2,64 & 2,76 & 2,71 & 2,76 & 2,25 & 2,48 & 2,73 & 2,17 & 2,53 & 2,59 & 2,36 & 2,25 & 2,28 \\
\hline $\mathrm{K} 2 \mathrm{O}$ & 1,25 & 1,06 & 2,12 & 2,01 & 1,52 & 1,78 & 1,29 & 1,24 & 1,13 & 1,09 & 1,25 & 0,98 & 1,48 & 0,88 & 1,16 & 1,19 & 1,16 \\
\hline $\mathrm{P} 2 \mathrm{O} 5$ & 0,541 & 0,357 & 0,707 & 0,644 & 0,521 & 1,115 & 0,567 & 0,517 & 0,306 & 0,430 & 0,543 & 0,269 & 0,367 & 0,287 & 0,395 & 0,365 & 0,315 \\
\hline $\mathrm{LOI}$ & 0,88 & 0,82 & 0,4 & 0,46 & 0,32 & 0,76 & 0,48 & 0,62 & 0,18 & 0,74 & 0,12 & 0,10 & 0,14 & - & 0,27 & 0,14 & 0,16 \\
\hline $\mathrm{T}$ Total & 99,531 & 99,511 & 99,05 & 98,75 & 99,59 & 98,91 & 99,16 & 99,69 & 99,10 & 98,95 & 99,46 & 99,63 & 99,31 & 99,94 & 99,19 & 98,85 & 99,38 \\
\hline
\end{tabular}

Trace elements (in ppm)

\begin{tabular}{|c|c|c|c|c|c|c|c|c|c|c|c|c|c|c|c|c|c|}
\hline $\mathrm{Ba}$ & 577 & 733 & 681 & 616 & 439 & 1033 & 483 & 436 & 356 & 423 & 462 & 318 & 461 & 233 & 412 & 353 & 332 \\
\hline $\mathrm{Ce}$ & 104 & 102 & 87 & 123 & 82 & 137 & 122 & 107 & 88 & 104 & 116 & 101 & 123 & 102 & 91 & 96 & 75 \\
\hline Co & 38 & 40 & 32 & 50 & 28 & 18 & 29 & 34 & 40 & 33 & 34 & 34 & 35 & 30 & 33 & 42 & 41 \\
\hline $\mathrm{Cr}$ & 22 & 40 & - & - & - & 21 & 19 & - & 82 & - & - & 84 & 144 & 74 & 44 & 113 & 77 \\
\hline $\mathrm{Cu}$ & 205 & 143 & 212 & 243 & 59 & 9 & 46 & 63 & 259 & 107 & 63 & 271 & 165 & 273 & 235 & 207 & 294 \\
\hline $\mathrm{F}$ & 886 & 657 & 870 & 1101 & 678 & 1061 & 985 & 706 & 942 & 862 & - & - & - & - & - & 658 & - \\
\hline $\mathrm{Ga}$ & 24 & 23 & 29 & 27 & 27 & 26 & 25 & 25 & 22 & 24 & 25 & 22 & 22 & 21 & 22 & 23 & 21 \\
\hline $\mathrm{La}$ & 36,7 & - & 45 & 42 & 29 & 45 & 40 & 38 & 33 & 34 & 46 & 30 & 27 & 30 & 28 & 33 & 52 \\
\hline $\mathrm{Nb}$ & 24 & 20 & 31 & 25 & 23 & 27 & 24 & 22 & 17 & 21 & 22 & 15 & 21 & 14 & 18 & 19 & 15 \\
\hline $\mathrm{Nd}$ & 64 & 53 & 43 & 66 & 38 & 65 & 50 & 59 & 47 & 58 & 54 & 48 & 49 & 39 & 46 & 55 & 44 \\
\hline $\mathrm{Ni}$ & 32 & 38 & 21 & 37 & 22 & - & 26 & 23 & 56 & 21 & 26 & 49 & 81 & 47 & 46 & 79 & 51 \\
\hline $\mathrm{Pb}$ & 6 & 5 & 17 & 8 & 6 & 6 & 4 & 8 & 7 & 6 & 5 & 5 & 11 & 8 & 8 & 7 & 6 \\
\hline $\mathrm{Rb}$ & 31 & 33 & 51 & 44 & 33 & 32 & 32 & 33 & 25 & 34 & 29 & 18 & 31 & 17 & 35 & 23 & 30 \\
\hline $\mathrm{S}$ & - & - & - & - & - & - & - & - & 348 & 330 & - & - & - & - & - & - & - \\
\hline $\mathrm{Sc}$ & 28 & 32 & 23 & 26 & 27 & 25 & 27 & 32 & 43 & 31 & 31 & 42 & 33 & 41 & 35 & 34 & 41 \\
\hline $\mathrm{Sr}$ & 493 & 450 & 854 & 884 & 486 & 722 & 544 & 497 & 303 & 481 & 507 & 329 & 385 & 251 & 380 & 459 & 312 \\
\hline Th & 10 & 10 & 14 & 10 & 13 & 8 & 8 & 9 & 8 & 10 & 9 & 7 & 7 & 7 & 9 & 8 & 8 \\
\hline $\mathrm{U}$ & - & - & 6 & 5 & 9 & 4 & 4 & 3 & - & - & 3 & 5 & 3 & 7 & 4 & - & - \\
\hline V & 401 & 503 & 366 & 394 & 383 & 199 & 433 & 424 & 436 & 466 & 406 & 444 & 383 & 416 & 460 & 464 & 453 \\
\hline Y & 40 & 34 & 127 & 38 & 40 & 61 & 37 & 38 & 37 & 35 & 39 & 36 & 37 & 44 & 35 & 32 & 39 \\
\hline $\mathrm{Zn}$ & 137 & 132 & 127 & 128 & 123 & 171 & 127 & 135 & 113 & 127 & 133 & 122 & 132 & 130 & 124 & 120 & 134 \\
\hline $\mathrm{Zr}$ & 271 & 219 & 315 & 288 & 273 & 318 & 279 & 273 & 199 & 232 & 275 & 174 & 250 & 200 & 200 & 214 & 186 \\
\hline
\end{tabular}



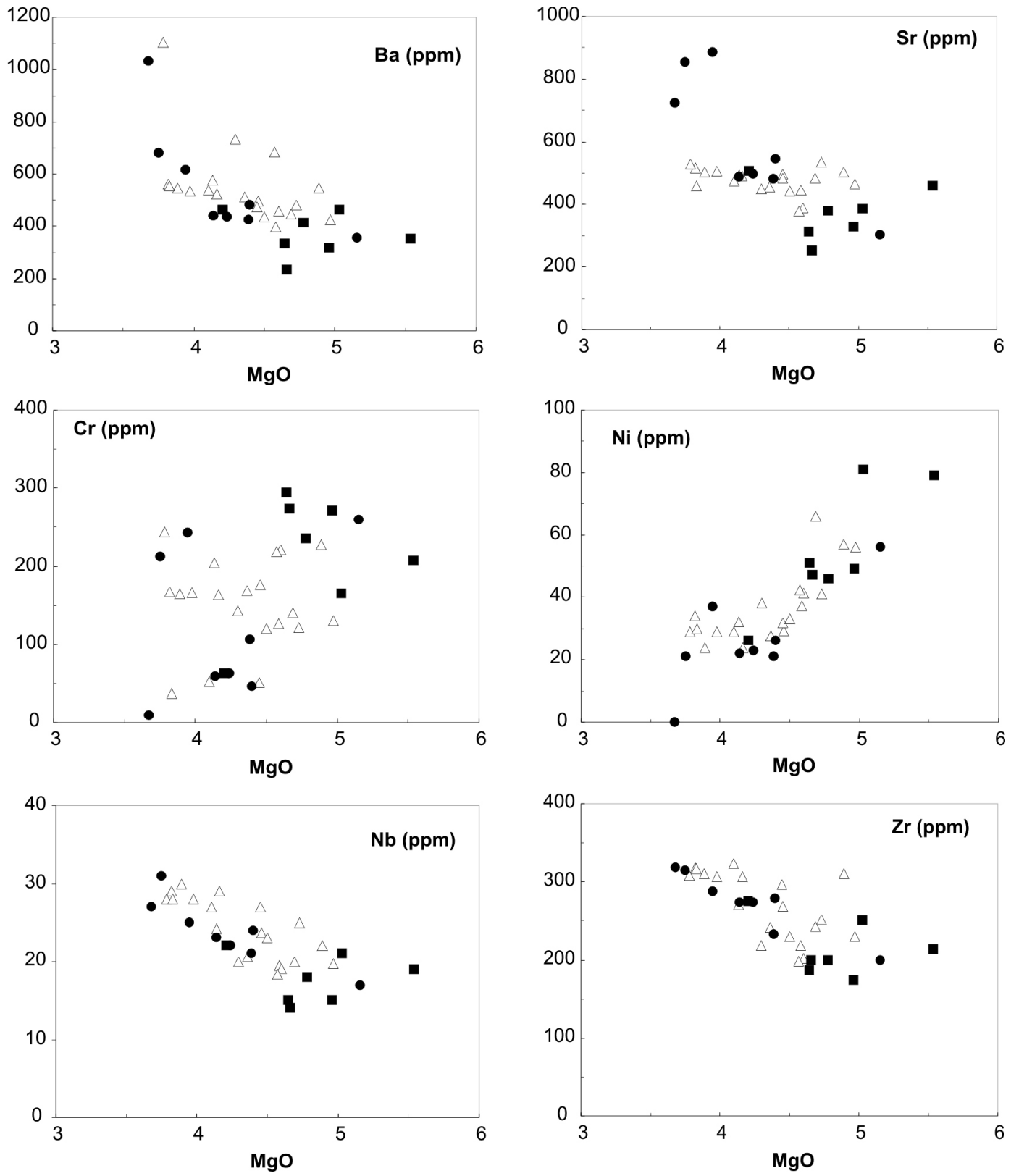

Figure 6-Trace-element variation diagrams using $\mathrm{MgO}$ as a differentiation index for PEMP basalts. Symbols: open triangles, flows; closed circles, sills; closed squares, dikes.

boundary between the dacite and trachydacite fields; for simplicity, they will be referred to as "dacites" in this work.

Major and trace-element variations with fractionation Figure 5 and 6 are variation diagrams for the Piraju-Ourinhos basalts using $\mathrm{MgO}$ as a differentiation index, respectively for the major and minor oxides and for the trace-elements. Some well-defined chemical correlations can be observed, reflecting magmatic differentiation processes that provoked the reduction of the $\mathrm{CaO}, \mathrm{Ni}, \mathrm{Cr}$ and $\mathrm{V}$ contents, pointing to a fractionation dominated by pyroxenes, calcic plagioclase and Fe$\mathrm{Ti}$ oxides. In contrast, elements as $\mathrm{P}, \mathrm{Ba}, \mathrm{Nb}$ and $\mathrm{Zr}$ show an incompatible behavior. A scattering of the Al, $\mathrm{Ti}$ and $\mathrm{Sr}$ contents is partly due to the fractionation of plagioclase and Fe-Ti oxides, but also seems to reflect the existence of contrasted types of basaltmagma types (see below).

Some of the systematic contrasts can be correlated with the mode of occurrence of the basic rocks. Thus, most of the dikes are slightly more primitive (with $\mathrm{MgO}$ contents above $4.5 \mathrm{wt} \%$ and greater contents of compatible trace-elements such as $\mathrm{Cr}, \mathrm{Ni}$ and $\mathrm{Sc}$ ), and have lower $\mathrm{TiO}_{2}$ as compared to the flows and sills (Fig. 5). A few sill samples are distinct, and appear to derive from a different magma; in particular, the remarkably higher Sr contents of the two samples from a sill located south of Timburi (OU-199 and OU170 , with $850-880 \mathrm{ppm} \mathrm{Sr}$, versus $440-540 \mathrm{ppm}$ in the flows) suggest affinities with the Urubici-type basalts (see below). 
Rare-earth elements and incompatible-element normalized diagrams Chondrite-normalized rareearth element diagrams (Fig. 7) illustrate the contrasts between different groups of basic rocks in the region. The flows have similar slightly fractionated REE patterns $[(\mathrm{La} / \mathrm{Yb}) \mathrm{n}=6.3-8.5 ;(\mathrm{Tb} / \mathrm{Yb}) \mathrm{n}=1.6-2]$ which are shared by part of the sills and dikes. However, sill sample OU-199 shows a more fractionated pattern with $(\mathrm{La} / \mathrm{Yb}) \mathrm{n}=11$ and $(\mathrm{Tb} / \mathrm{Yb}) \mathrm{n}=2.3$, while two dikes have less fractionated patterns with $(\mathrm{La} / \mathrm{Yb}) \mathrm{n}=3.5-4.3$ and $(\mathrm{Tb} / \mathrm{Yb}) \mathrm{n}=1.3$.

The primitive mantle-normalized incompatibleelement patterns highlight these contrasts further. Sill OU-199 shows a distinctive pattern, more fractionated than the flows, with a distinctively less pronounced $\mathrm{Sr}$ trough (Fig. 8a). The two dikes, in contrast, are the least fractionated, and the poorest in all elements more incompatible than Ti (Fig. 8b).

These contrasts are compared in figure 9 with the spidergrams for typical high-Ti magma types defined by Peate (1997). It can be observed that the flow samples, as well as the chemically similar sills and dikes, are similar to the Pitanga-type basalts, whereas sill OU-199 is comparable to the Urubici-type basalts, which contrast with the Pitanga-type mainly because of their higher Sr and more fractionated incompatibleelement patterns. The patterns of the least fractionated dikes, on the other hand, are much similar to those of the Paranapanema-type basalts (Fig. 9); their contents of some LILE ( $\mathrm{Sr}, \mathrm{Rb}, \mathrm{Ba}$, Th and especially $\mathrm{U}$ ) are however clearly lower, which might point to lesser contribution from a LILE-rich source, a possibility which requires further investigation.

Such correlations are further illustrated by the binary diagrams that use the discrimination criteria used by Peate et al. (1992) and Peate (1997) (Fig. 10). These diagrams show that the Paranapanema-type dikes can be distinguished by their lower $\mathrm{Sr}, \mathrm{Ti} / \mathrm{Y}$ and $\mathrm{Zr} / \mathrm{Y}$; it can also be seen that $\mathrm{Ti} / \mathrm{Y}$ is a better discriminant compared to $\mathrm{TiO}_{2}$, since two dikes otherwise showing Pitangatype chemistry would be classified as Paranapanema type in the $\mathrm{Fe}_{2} \mathrm{O}_{3} \times \mathrm{TiO}_{2}$ diagram because of their least differentiated character. Sample OU-261, the only from the huge Fartura sill analysed in this work, groups in all diagrams with the Paranapanema type dikes. A scrutiny of the analyses presented by Raposo (1987) suggests that rocks with chemical characteristics similar to both the Pitanga and Paranapanema types are present in the Fartura sill, suggesting a multi-intrusive nature that needs to be confirmed in future studies.

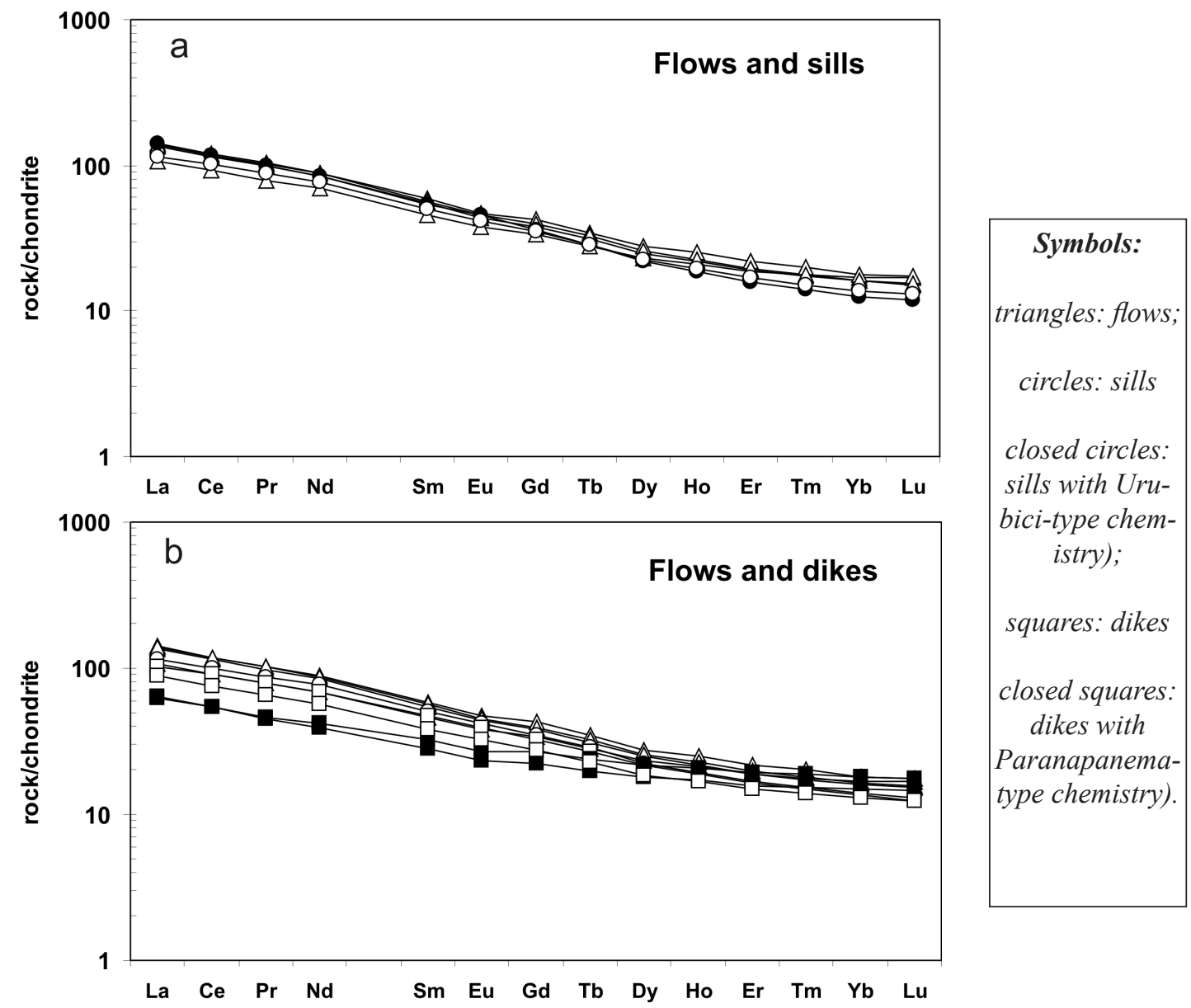

Figure 7 - Chondrite-normalized (McDonough \& Sun, 1995) REE patterns for basalts from the Piraju-Ourinhos region: (a) flows compared to sills; (b) flows compared to dikes. 
Table 2 - Results of chemical analyses of trace-elements (by ICPMS, in ppm) of basaltic rocks from the Piraju-Ourinhos region.

\begin{tabular}{|c|c|c|c|c|c|c|c|c|c|c|}
\hline Sample & OU-264 & OU-358 & OU-362 & OU-371 & OU-199 & OU-244 & OU-21 & OU-22 & OU-50 & OU-251 \\
\hline $\mathrm{Rb}$ & 25.2 & 45.8 & 34.8 & 33.9 & 39.6 & 31.6 & 26.8 & 16.3 & 14.7 & 22.9 \\
\hline $\mathrm{Sr}$ & 478 & 454 & 503 & 485 & 811 & 520 & 460 & 293 & 217 & 451 \\
\hline Y & 38.7 & 39.1 & 49.6 & 38.2 & 33.4 & 34.2 & 34.5 & 31.7 & 40 & 30.5 \\
\hline $\mathrm{Zr}$ & 248 & 329 & 301 & 300 & 279 & 275 & 255 & 158 & 175 & 212 \\
\hline $\mathrm{Nb}$ & 22.3 & 28.9 & 28.1 & 28.8 & 26.6 & 25.5 & 21 & 12.9 & 12.4 & 19.8 \\
\hline Cs & 0.53 & 0.57 & 0.48 & 0.38 & 0.77 & 0.97 & 0.57 & 1.75 & 0.14 & 0.15 \\
\hline $\mathrm{Ba}$ & 429 & 576 & 1131 & 540 & 612 & 485 & 428 & 281 & 216 & 366 \\
\hline $\mathrm{La}$ & 33.2 & 42.2 & 44 & 42.8 & 43.3 & 35.7 & 31.8 & 19.8 & 19.4 & 27.5 \\
\hline $\mathrm{CE}$ & 74.2 & 93.4 & 96.1 & 94.8 & 94 & 81.5 & 73.2 & 43.5 & 43.7 & 61.6 \\
\hline $\operatorname{Pr}$ & 9.67 & 12 & 12.6 & 12.4 & 12.1 & 10.7 & 9.56 & 5.46 & 5.67 & 8.02 \\
\hline $\mathrm{Nd}$ & 41.4 & 50.4 & 53.5 & 52.3 & 50.8 & 45.9 & 41.5 & 23.5 & 25.2 & \\
\hline $\mathrm{Sm}$ & 8.99 & 10.7 & 11.4 & 11.1 & 10.6 & 9.84 & 9.17 & 5.48 & 6.33 & 7.51 \\
\hline $\mathrm{Eu}$ & 2.79 & 3.2 & 3.44 & 3.34 & 3.34 & 3.06 & 2.86 & 1.71 & 1.99 & 2.37 \\
\hline Gd & 8.7 & 9.87 & 11 & 10.2 & 9.38 & 9.04 & 8.44 & 5.79 & 6.97 & 7.09 \\
\hline $\mathrm{Tb}$ & 1.32 & 1.48 & 1.63 & 1.54 & 1.36 & 1.35 & 1.27 & 0.93 & 1.12 & 1.08 \\
\hline Dy & 7.46 & 8.02 & 8.93 & 8.29 & 7.08 & 7.23 & 7.01 & 5.75 & 7.02 & 5.99 \\
\hline Но & 1.51 & 1.57 & 1.8 & 1.63 & 1.33 & 1.4 & 1.36 & 1.23 & 1.5 & 1.2 \\
\hline $\mathrm{Er}$ & 3.94 & 4 & 4.6 & 4.14 & 3.35 & 3.53 & 3.44 & 3.3 & 4.02 & 3.11 \\
\hline $\mathrm{Tm}$ & 0.57 & 0.56 & 0.65 & 0.58 & 0.45 & 0.49 & 0.48 & 0.5 & 0.61 & 0.45 \\
\hline $\mathrm{Yb}$ & 3.54 & 3.34 & 3.72 & 3.4 & 2.61 & 2.88 & 2.85 & 3.14 & 3.79 & 2.71 \\
\hline $\mathrm{Lu}$ & 0.54 & 0.49 & 0.56 & 0.5 & 0.38 & 0.42 & 0.4 & 0.47 & 0.56 & 0.4 \\
\hline $\mathrm{Hf}$ & 6.26 & 8.31 & 7.99 & 7.88 & 6.83 & 7.05 & 5.97 & 3.83 & 4.4 & 5.4 \\
\hline $\mathrm{Ta}$ & 1.51 & 1.92 & 1.89 & 1.96 & 1.71 & 1.75 & 1.32 & 0.86 & 0.77 & 1.41 \\
\hline $\mathrm{Pb}$ & 4.45 & 5.63 & 5.26 & 5.3 & 6.9 & 4.54 & 4.32 & 3.3 & 2.62 & 3.65 \\
\hline Th & 3 & 4.15 & 3.7 & 3.73 & 4.27 & 3.23 & 2.84 & 2.16 & 1.88 & 2.53 \\
\hline U & 0.59 & 0.87 & 0.75 & 0.75 & 0.97 & 0.66 & 0.56 & 0.4 & 0.36 & 0.51 \\
\hline
\end{tabular}

The Urubici-type sills are distinguished by their higher $\mathrm{Sr}$ contents as well as high $\mathrm{TiO}_{2}$ at relatively low $\mathrm{Fe}_{2} \mathrm{O}_{3}$ and higher $\mathrm{La} / \mathrm{Yb}(\mathrm{n})$ and $\mathrm{Tb} / \mathrm{Yb}(\mathrm{n})$. In contrast with the criteria adopted by Peate (1997), lower Ti/Zr and higher $\mathrm{Zr} / \mathrm{Y}$ do not clearly distinguish these samples from the Pitanga-type basalts. This is a reflection of $\mathrm{Zr}$ contents slightly lower than those of the typical Urubici basalts, not surprisingly showing that they do not exactly match the composition of the samples used by Peate (1997), which come from the southern portion of the Paraná Basin. Also worth mentioning is that a few samples (two sills and one flow) fall outside the fields defined by Peate (1997) due to high Y contents (60-130 $\mathrm{ppm})$, the reason for which is presently unexplained.
IMPLICATIONS FOR THE BASALT STRATIGRAPHY IN THE REGION Rock chemistry has been shown to be a fundamental tool to the definition of the stratigraphy of continental flood basalt provinces; detailed studies carried out in the Columbia River Basalt and Deccan provinces were successful in identifying a chemical stratigraphy and flow by flow correlations in selected areas (e.g., Mangan et al. 1986, Cox \& Hawkesworth, 1985). In the PEMP, the recognition of important chemical variations which allowed the identification of at least seven basalt magma types of regional expression (Peate et al., 1992; Peate, 1997) has also stimulated the use of rock chemistry as a stratigraphic tool.

The geochemical results here presented show 

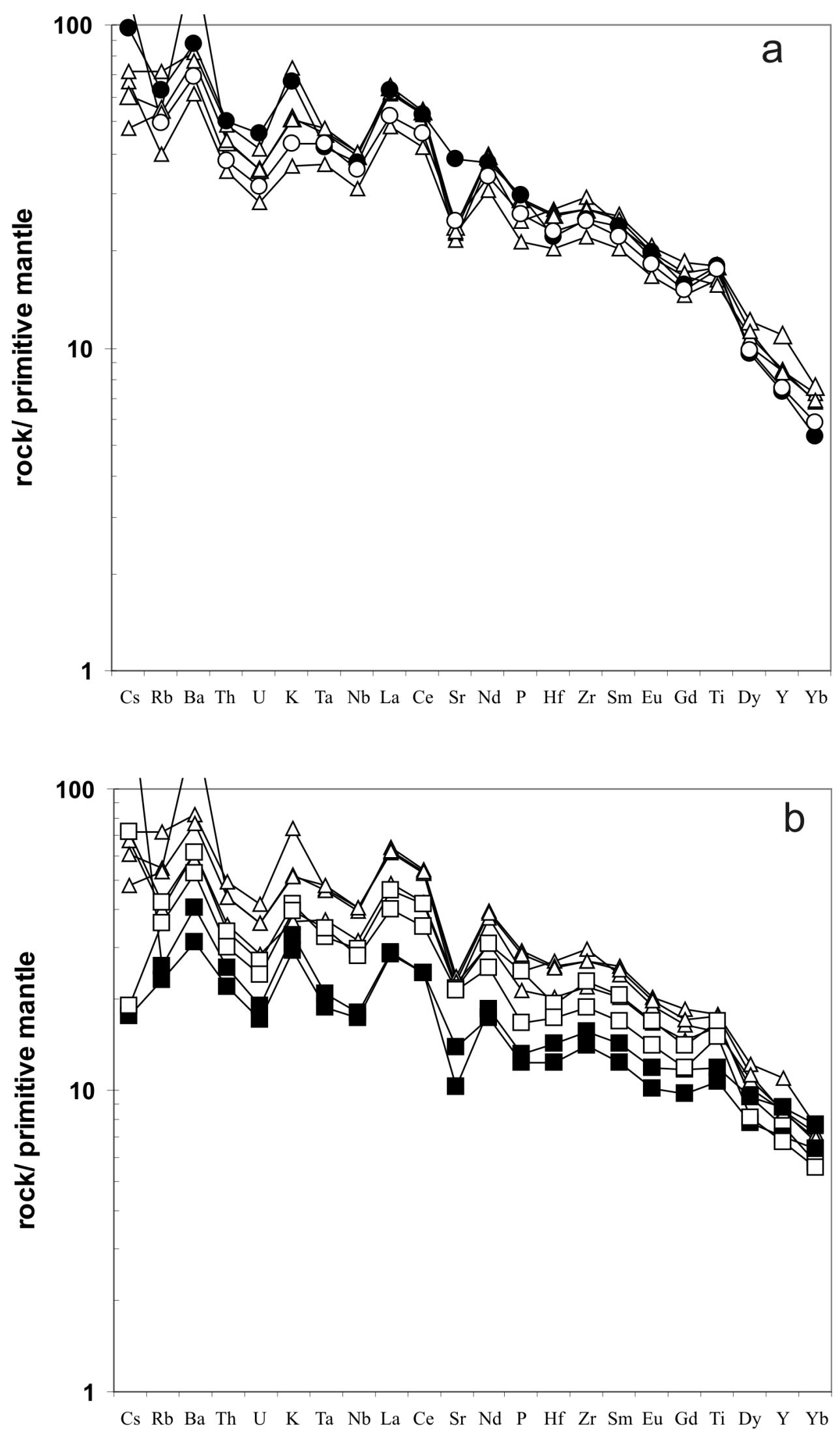

Figure 8 - Primitive-mantle normalized (Sun \& McDonough, 1989) incompatible element patterns for basalts from the Piraju-Ourinhos region: (a) flows compared to sills; (b) flows compared to dikes. Symbols: triangles: flows; circles: sills; closed circles: sills with Urubici-type chemistry); squares: dikes; closed squares: with Paranapanema-type chemistry). 


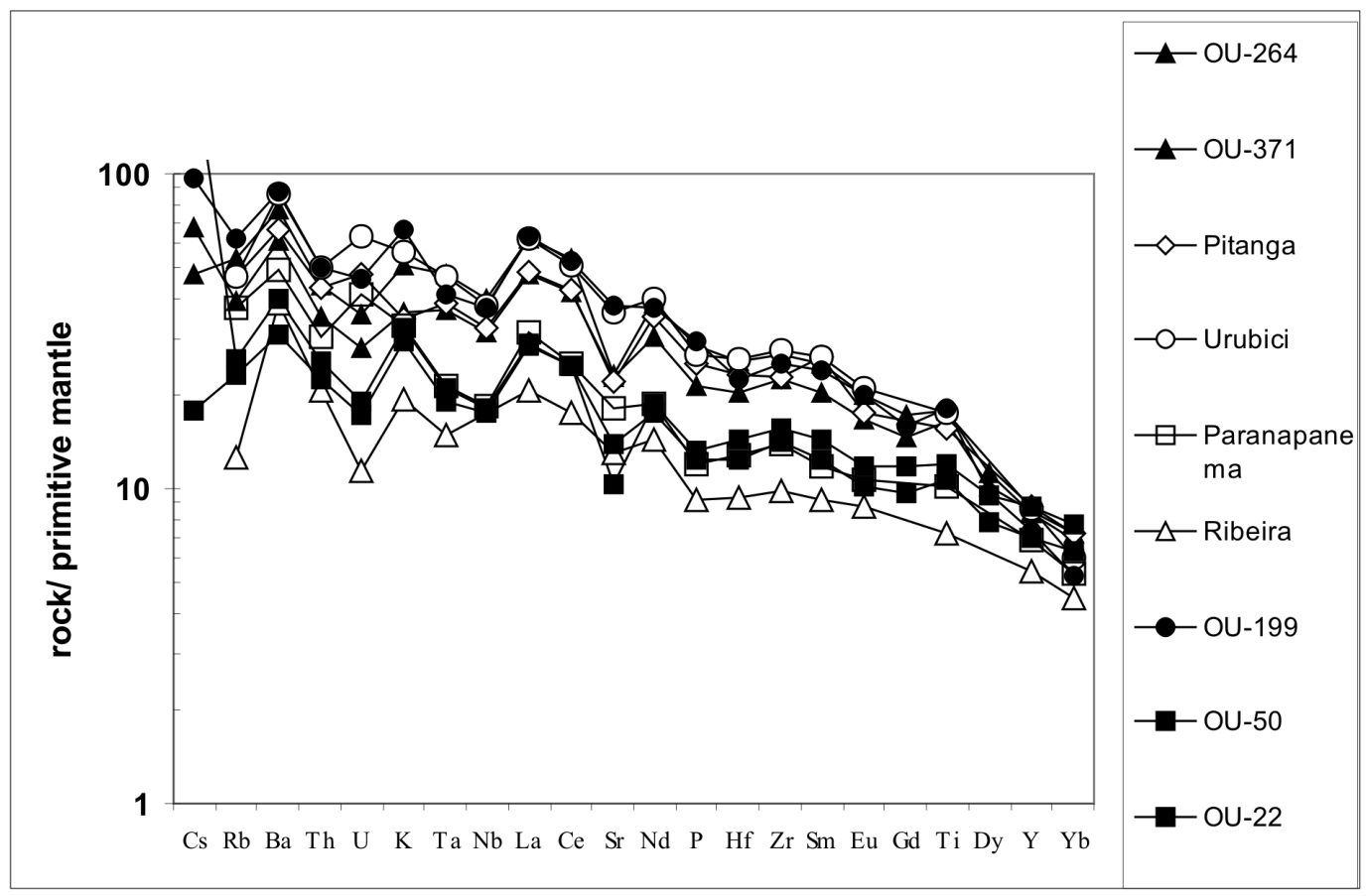

Figure 9 - Primitive-mantle normalized (Sun \& McDonough, 1989) incompatible element patterns for basalts from the Piraju-Ourinhos region compared to the patterns shown by high Ti/Y basalts (analyses from Peate, 1997).
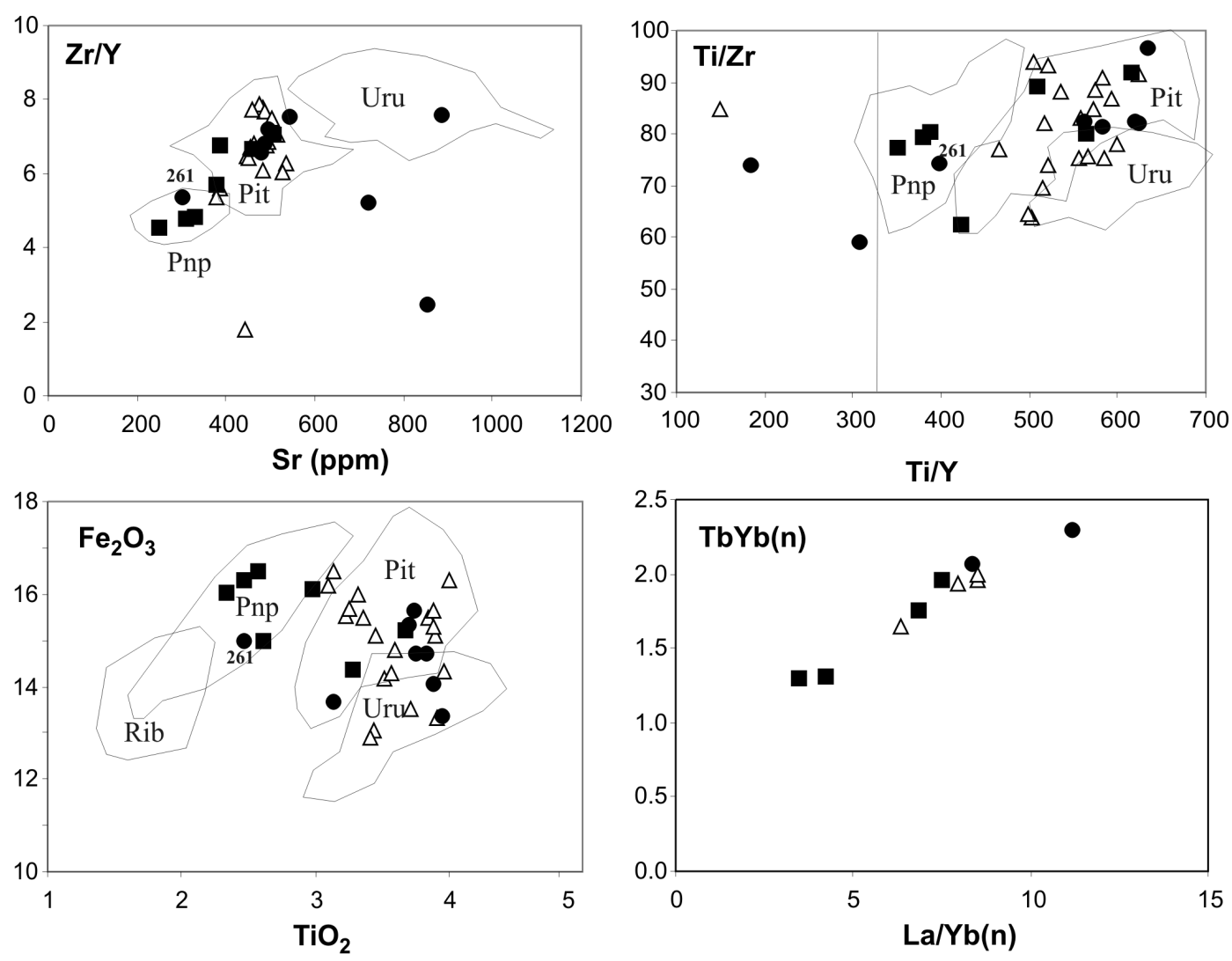

Figure 10 - Situation of basic rocks from the Piraju-Ourinhos region in binary diagrams discriminating the different types of high Ti/Y basalt from the PEMP (compositional fields drawn after the distribution of analyses from Peate, 1997: Rb= Ribeira; Pnp= Paranapanema; Pit= Pitanga; Uru= Urubici). Symbols: open triangles, flows; closed circles, sills; closed squares, dikes. 
that the basaltic flows of the Piraju-Ourinhos region can be classified as Pitanga-type, in accordance with regional maps that show this magma type covering most of the central portion of the State of São Paulo and nearby areas (Peate, 1997; Rocha Jr. et al., 2005). In contrast, though most of the sills and some dikes have a chemical composition similar to the flows, it is remarkable that a part of the analysed diabase dikes show a contrasted geochemical signature, correlative to Paranapanema basalt magma type. This observation is also consistent with the regional stratigraphic panorama, with the Paranapanema type flows showing slightly younger absolute Ar-Ar ages, and overlying the Pitanga-type flows (Stewart et al., 1996; Peate, 1997). The basalt flow isopach maps show that in the studied area, which is located at the NE fringe of the region affected by uplift of the Ponta Grossa Arch (e.g., Raposo \& Ernesto, 1995), the original thickness of the basalt flows must have been much greater than currently observed, and it may be inferred that upper Paranapanema type flows, which were fed by the chemically equivalent dikes, have been eroded.

The apparent existence of Urubici-type sills, suggested by the Timburi occurrence, is peculiar, since occurrences of this basalt type were not reported so far in the Ponta Grossa Arch region. Recent work has shown that basalts with such chemical affinities have an area of occurrence wider than previously reported, being especially remarkable the newly found exposures in the northeastern portion of the State of São Paulo (Rocha Jr. et al., 2005). The geochemical picture presented here is still preliminary, and highlights the importance of this tool to identify the flow stratigraphy. In a more detailed scale, subtler differences, or discrimination parameters not previously used may help identify particular flows; this is indicated for instance by the textural and geochemical contrasts between the basalts located immediately to the north of the Paranapanema River and those situated in the Santa Cruz do Rio Pardo -Águas de Santa Bárbara region (Fig. 1).

Contrasting with the basalts and equivalent intrusives, the acidic magmatism show a remarkably homogeneous chemistry, that appears to be independent of geographic or stratigraphic position (Janasi et al, 2005).

Acknowldegements This work was financed by a grant from Fundação de Amparo à Pesquisa do Estado de São Paulo (Fapesp) (Proc. 03/06259-4) to TJM. VAF and PMR acknowledge Scientific Initiation scholarships from Fapesp and $\mathrm{CNPq}$, respectively.

\section{References}

Beane J.E., Turner C.A., Hooper P.R., Subbarao K.V., Walsh J.N. 1986. Stratigraphy, composition and form of Deccan Basalts, Western Ghats, India. Bulletin of Volcanology, 48:61-83.

Bellieni G., Comin-Chiaramonti P., Marques L.S., Melfi A.J., Nardy A.J.R., Papatrechas C., Piccirillo E.M., Roisenberg A., Stolfa D. 1986. Petrogenetic aspects of acid and basaltic lavas from the Paraná Plateau (Brazil): geological, mineralogical and petrochemical relationships. J. Petrology., 27: 915-944.

Bellieni G., Piccirillo E.M., Comin-Chiaramonti P., Melfi A.J. 1988. Mineral chemistry of continental stratroid volcanics and related intrusives from Paraná Basin (Brazil). In: E.M.Piccirillo, A.F. Melfi (eds.) The Mesozoic flood volcanism of the Paraná Basin. Instituto Astronômico e Geofísico (USP), p. 73-92.

CPRM 1980. Geologia do Bloco SF-22-W. Relatório Final. Projeto Paulipetro, Consórcio CESP/IPT, 89 p.

Cox K.G. \& Hawkesworth C.J. 1985. Geochemical stratigraphy of the Deccan Traps at Mahabaleshwar, Western Ghats, India, with implications for open system magmatic processes. J. Petrology, 26:355-377.

Ernesto M., Raposo M.I., Marques L.S., Renne P.R., Diogo L.A., de Min A. 1999. Paleomagnetism, geochemistry and ${ }^{40} \mathrm{Ar}^{-39} \mathrm{Ar}$ dating of the North-eastern Paraná Magmatic Province: tectonic implications. Journal of Geodynamics, 28:321-340.

IPT 1994. Estudos geológico-geotécnicos na área do barramento de Ourinhos (Eixo Corredeira), SP. Relatório $\mathrm{n}^{0}$ 32.304, Instituto de Pesquisas Tecnológicas, $80 \mathrm{p}$.
Iyomasa W.S., Fernandes L.A., Frascá M.H.B.O., Scarrmínio M. 1994. As rochas vulcânicas ácidas da Formação Serra Geral no vale do Rio Paranapanema (SP/PR). In: SBG, Congr. Bras. Geol., 38, Balneário de Camboriú, Boletim de Resumos, p. 107-108.

Janasi V.A., Montanheiro T.J., Dantas F.A., Reis P.M., Freitas V.A., Yamamoto J.K. 2005. Aspectos geológicos, petrográficos e químicos do vulcanismo ácido da Bacia do Paraná na região de Piraju-Ourinhos (SP). In: SBG, Simpósio de Vulcanismo e Ambientes Associados, 3, Cabo Frio-RJ, atas, CD-ROM.

Janasi V.A., Montanheiro T.J., Freitas V.A., Reis P.M., Negri F.A., Dantas F.A. 2007. Geological, petrographic and geochemical aspescts of the acid volcanism of the Paraná Magmatic Province in the Piraju-Ourinhos region. Rev. Bras. Geoc. (Artigo submetido em 27/04/2007).

Le Bas M.J., Le Maitre R.W., Streckeisen A., Zanettin B. 1986. A chemical classification of igneous rocks based on the total alkali-silica diagram. J. Petrology, 27:745750 .

Luchetti A.C.F., Machado F.B., Nardy A.J.R., Squisato E., Oliveira M.A.F. 2005 Litoestratigrafia e litogeoquímica das rochas vulcânicas ácidas associadas ao vulcanismo Serra Geral. In: SBG, Simpósio de Vulcanismo e Ambientes Associados, 3, Cabo Frio-RJ, Atas, CDROM.

Mangan M.T., Wright T.L., Swanson D.A., Byerly G.R. 1986. Regional correlation of the Grande Ronde Flows, Columbia River Basalt Group, Washington, Oregon and Idaho. Geol. Soc. Amer. Bulletin, 97:1300-1318 
Mcdonough W.F. \& Sun S.S. 1995. The composition of the Earth. Chemical Geology, 120: 223-253.

Montanheiro T.J. 1999. Prospecção e caracterização de pozolanas na Bacia do Paraná, Estado de São Paulo. Tese de Doutoramento, Instituto de Geociências, Universidade de São Paulo, 226p.

Mori P.E., Reeves S., Correia C.T., Haukka M. 1999. Development of a fused glass disc XRF facility and comparison with the pressed powder pellet technique at Instituto de Geociências, Universidade de São Paulo. Rev. Bras. Geoc., 29:441-446.

Nardy A.J.R., Oliveira M.A.F, Betancourt R.H.S., Verdugo D.R.H., Machado F.B. 2002. Geologia e estratigrafia da Formação Serra Geral, SP. Geociências, 21:15-32.

Nardy A.J.R., Squisato E., Machado F.B., Oliveira M.A.F. 2005. Os derrames básicos da borda leste da Bacia do Paraná no Estado de São Paulo: considerações preliminares. In: Simpósio de Vulcanismo e Ambientes Associados, 3, Cabo Frio - RJ, Atas, CD-ROM.

Navarro M.S. 2004. A implantação de rotina, e seu refinamento, para a determinação de elementos terras raras em materiais geológicos por ICP-OES e ICP-MS. Aplicação ao caso dos granitóides de Piedade-Ibiúna (SP) e Cunhaporanga (PR). Dissertação de Mestrado, Instituto de Geociências, Universidade de São Paulo, $132 \mathrm{p}$.

Negri F.A., Montanheiro T.J., Janasi V.A., Reis P.M. 2006. Mapa de distribuição das rochas vulcânicas nas folhas Piraju/SP e Jacarezinho/SP-PR. In: SBG, Congr. Bras. Geol., 43, Aracaju, Anais, p. 247.

Peate D.W., Hawkesworth C.J., Mantovani M.S.M. 1992. Chemical Stratigraphy of the Paraná Lavas (South America): classification of magma types and their spatial distribuition. Bulletin of Volcanology, 55:119-139.

Peate D. W. 1997. The Paraná-Etendeka Province. In: J.J. Mahoney Coffin M.F. (eds.) Large Igneous Provinces.
Geophysical Monograph 100, AGU, p. 217-245.

Raposo M.I. 1987. Evolução magmática e petrológica das rochas vulcânicas ácidas mesozóicas da região de Piraju-Ourinhos (SP e PR). Dissertação de Mestrado, Instituto Astronômico e Geofísico, Universidade de São Paulo, $159 \mathrm{p}$.

Raposo M.I. \& Ernesto M. 1995. An Early Cretaceous paleomagnetic pole from Ponta Grossa dikes (Brazil): Implications for the South American Mesozoic apparent polar Wander path. J. Geophys. Res., 100:20095-20110.

Reidel S.P. 1998. Emplacement of Columbia River flood basalt. J. Geophys. Res., 103:27293-27410.

Rocha Jr. E.R.V., Marques L.S., Figueiredo A.M.G. 2005. Concentrações de terras raras e outros elementos traços em rochas intrusivas e extrusivas do norte da Província Magmática do Paraná: resultados preliminares. In: Simpósio de Vulcanismo e Ambientes Associados, 3, Cabo Frio - RJ, Atas, CD-ROM.

Ruegg N.R. \& Amaral G. 1976. Variação regional da composição químicas das rochas basálticas da Bacia do Paraná. Boletim do Instituto de Geociências USP, 7:131147.

Stewart K., Turner S., Kelley S., Hawkesworth C., Kirstein L., Mantovani M. 1996. 3-D, ${ }^{40} \mathrm{Ar}-{ }^{39} \mathrm{Ar}$ geochronology in the Paraná continental flood basalt province. Earth Planet. Sci. Letters, 143:95-109.

Sun S.S. \& McDonough W.F. 1989. Chemical and isotopic systematics of oceanic basalts: Implications for mantle composition and processes. In: A.D. Saunders \& M.J. Norry (eds.) Magmatism in the ocean basins. Geological Society Special Publication, 42:313-345.

Manuscrito AE-059/2006

Recebido em 22 de novembro de 2006 Aceito em 04 de abril de 2007 